\title{
Physical, chemical, and microbiological stability study of diluted atropine eye drops
}

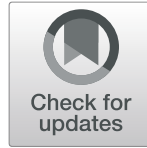

Jumpei Saito ${ }^{1,2^{*}}$, Hitomi Imaizumi ${ }^{1}$ and Akimasa Yamatani ${ }^{1,2}$

\begin{abstract}
Background: Atropine eye drops are indicated for juvenile myopia progression, cycloplegia, amblyopia, and strabismus. According to the package insert, $10 \mathrm{mg} / \mathrm{mL}$ atropine eye drops must be diluted for pediatric patients to prevent systemic adverse effects. Compounding units in hospital pharmaceutical departments or community pharmacies are compelled to prepare this essential medication; however, validated atropine stability data is limited and the shelf life after preparation is extremely short. As it is a long-term treatment, a longer shelf life is necessary to improve patient care. This study aimed to demonstrate the physical, chemical, and microbiological stability of diluted atropine eye drops over a period of six months.

Methods: Preparation consists of dilution of a $10 \mathrm{mg} / \mathrm{mL}$ atropine solution (Nitten Atropine Ophthalmic Solution 1\%; Nitten Pharmaceutical Co., Ltd.) in $0.9 \% \mathrm{NaCl}$ to concentrations of $0.1,1.0,2.5$, and $5.0 \mathrm{mg} / \mathrm{mL}$, followed by a sterilizing filtration procedure and then an aseptic filling process of $5 \mathrm{~mL}$ in $5 \mathrm{~mL}$ polyethylene eyedropper bottles. The entire process is carried out in an overpressure isolator. All concentration products were kept for six months at $25^{\circ} \mathrm{C}$ or $5^{\circ} \mathrm{C}$. Visual inspection was conducted and $\mathrm{pH}$, osmolality, and atropine concentration were measured at day 0 , day 14 , day 28 , and every month until six months. Atropine concentration was measured using liquid chromatography tandem mass spectrometry. The sterility was monitored using a method adapted from the Japanese Pharmacopoeia sterility assay.
\end{abstract}

Results: Atropine remained within $\pm 5 \%$ of the target value in the six batches. Osmolality $(285 \mathrm{mOsm} / \mathrm{kg}$ ) as well as $\mathrm{pH}$ (5.88) were kept constant. No variations in solution characteristics (crystallization, discoloration) were noted. Sterility was maintained.

Conclusions: This study validated the physical, chemical, and microbiological stability of $0.1,1.0,2.5$, and $5.0 \mathrm{mg} / \mathrm{mL}$ atropine sulfate eye drops conserved inside polyethylene eyedroppers for six months at $25^{\circ} \mathrm{C}$ or $5^{\circ} \mathrm{C}$.

Keywords: Pediatric, Atropine, Eye drops

\section{Background}

Atropine is a nonselective muscarinic receptor antagonist, and atropine eye drops are frequently used for retardation of progressive myopia in children $[1,2]$. Results from research have demonstrated that a low concentration of atropine is useful in retarding myopia progression in a certain proportion of myopic schoolchildren. Atropine is also used for pediatric patients with cycloplegia, amblyopia, and strabismus. Treatments with

\footnotetext{
* Correspondence: saito-jn@ncchd.go.jp

'Department of Pharmacy, National Center for Child Health and Development, 2-10-1 Okura, Setagaya-ku, Tokyo 175-8535, Japan ${ }^{2}$ Division of Clinical Pharmacology and Oral Formulation Development, National Center for Child Health and Development, 2-10-1 Okura, Setagaya-ku, Tokyo 175-8535, Japan
}

higher concentrations of atropine eye drops are associated with a higher rate of dropout, a higher level of photophobia due to larger pupil size, and a lower amplitude of accommodation [2,3]. Dilution is necessary for treatment of pediatric patients. According to a previous report from Japan, except for patients under two years old, $1 \%$ eye drops showed a higher incidence rate of side effects than 0.5 and $0.25 \%$ eye drops [4].

In Japan and other countries, low-concentration atropine eye drops are not available as a licensed product. According to the package insert, $10 \mathrm{mg} / \mathrm{mL}$ atropine eye drops must be diluted for pediatric patients to prevent systemic adverse effects. To adjust the concentration, a self-dilution method is mandatory and compounding 
units in hospital pharmaceutical departments or community pharmacies are compelled to prepare this essential medication. However, long-term stability and sterility after preparation are not guaranteed. Additionally, there is the risk of inaccurate dosing.

For long-term treatment, a longer shelf life is necessary to improve patient care. This study aimed to demonstrate the physical, chemical, and microbiological stability of diluted atropine eye drops over a period of six months.

\section{Methods}

\section{Preparation and conservation of diluted atropine sulfate} solutions

A total of $100 \mathrm{~mL}$ of $0.1,1.0,2.5$, and $5.0 \mathrm{mg} / \mathrm{mL}$ solutions of atropine sulfate were prepared by diluting 1,10 , 25 , and $50 \mathrm{~mL}$ of $10 \mathrm{mg} / \mathrm{mL}$ atropine sulfate solution (Nitten Atropine Ophthalmic Solution 1\%; Lot number L1779K; expiration August 2020; Nitten Pharmaceutical Co., Ltd., Nagoya, Japan) in 99, 90, 75, and $50 \mathrm{~mL}$ of isotonic sodium chloride solution $(0.9 \% \mathrm{NaCl}$; Hikari Pharmaceutical Co., Ltd., Tokyo, Japan) to obtain 0.1, $1.0,2.5$, and $5 \mathrm{mg} / \mathrm{mL}$ solution $(0.01,0.1,0.25$, and $0.5 \%$ atropine sulfate solution). These solutions were sterilely dispensed at $5 \mathrm{~mL}$ per one bottle into sterilized white opaque polyethylene eyedropper squeezable bottles (Lot number 344161 J109; MI Chemical Co., Ltd., Hyogo, Japan) using an electron beam sterile syringe equipped with a $0.22 \mu \mathrm{m}$ pore size filter (Millex-GS; Lot number R8JA9816; Millipore, Darmstadt, Germany) in a laminar air flow microbiological safety cabinet.

\section{Study design}

The stability of $0.1,1.0,2.5$, and $5.0 \mathrm{mg} / \mathrm{mL}$ atropine solutions in multi-dose eyedropper bottles at $25^{\circ} \mathrm{C}$ as a typical room temperature condition and $5{ }^{\circ} \mathrm{C}$ as a refrigerated condition was assessed. The storage period was set at six months in order to ensure the longer usable time until the next medical examination.

\section{Stability of diluted atropine sulfate solution in multi-dose eyedroppers}

All atropine solutions were stored in a refrigerator (Sanyo Electric Co., Ltd., Osaka, Japan) temperature controlled at $5{ }^{\circ} \mathrm{C} \pm 1{ }^{\circ} \mathrm{C}$ or in a highly reliable accuracy oven (Fine Oven; Yamato Scientific Co., Ltd., Tokyo, Japan) at $25^{\circ} \mathrm{C} \pm 2{ }^{\circ} \mathrm{C}$ and at $60 \% \pm 5 \%$ residual humidity, until quantifications of atropine were performed. Visual inspection of the sample, atropine sulfate quantification, osmolality and $\mathrm{pH}$ measurements, and sterilization tests were carried out immediately after preparation, and at day 14 , day 28 , and every month until six months for each storage temperature.
Because the prepared eye drops supposed to be stored in the refrigerator and throw it away within one week once eye dropper opened in a clinical setting, the stability of diluted atropine sulfate solution only in unopened multi-dose eyedroppers was examined.

\section{Atropine sulfate quantification}

For each unit, atropine sulfate was quantified using a stability-indicating method adapted previously [5] by liquid chromatography (LC) using the system of LC-MS/ MS, which was an UltiMate 3000 HPLC system (Thermo Fisher Scientific K.K., Tokyo, Japan) with an analytical column (Unison UK-C18 column, $50 \mathrm{~mm} \times 3.0 \mathrm{~mm}$, i.d. $3 \mu \mathrm{m}$; Imtakt Corporation, Kyoto, Japan). The isocratic mobile phase consisted of a 40:60 (v/v) mixture of $0.1 \%$ $(\mathrm{v} / \mathrm{v})$ formic acid and acetonitrile. The flow rate of the mobile phase was $0.4 \mathrm{~mL} / \mathrm{min}$. The column temperature was set at $25^{\circ} \mathrm{C}$. Mass spectrometric detection was performed on a TSQ Vantage Triple Stage Quadrupole LC/ MS Mass Spectrometer (Thermo Fisher Scientific K.K., Tokyo, Japan). The injection volume was $2 \mu \mathrm{L}$. The electrospray source was operated in positive mode and mass spectrometer conditions (cone and collision energy) were optimized by direct infusion of the standards. Selected ion monitoring acquisition mode was used for the analysis in order to detect only specific mass ions during the analysis. The MS spectrum of atropine revealed a base peak at $\mathrm{m} / \mathrm{z} \mathrm{290}$, corresponding to the pseudomolecular ions $[\mathrm{M}+\mathrm{H}]^{+}$.

To determine the atropine sulfate concentration, 0.1, $1.0,2.5$, and $5.0 \mathrm{mg} / \mathrm{mL}$ of atropine sulfate concentration were diluted to $10,100,250$, and $500 \mathrm{ng} / \mathrm{mL}$ by using sterilized water and sterile filtered through $0.2 \mu \mathrm{m}$ filters (Cosmospin Filter-G; Lot number V8 M3934; Nacalai Tesque, Inc., Kyoto, Japan) to remove any particulate matter.

A calibration curve was prepared using seven concentrations of atropine, i.e., 5, 10, 50, 100, 500, 1000, and $5000 \mathrm{ng} / \mathrm{mL}$, and its linearity was verified three times on other days. If a calibration curve $R^{2}$ value is greater than 0.999 , it is acceptable for determination of atropine using the LC-MS/MS system.

Each day for three days, six solutions of $100 \mathrm{ng} / \mathrm{mL}$ were analyzed using a calibration curve prepared the same day. The method's precision was verified by confirming repeatability that was estimated by calculating the relative standard deviation (RSD) of intra-day analysis. Intermediate precision was assessed using RSD of inter-day analysis. Less than $5 \%$ was acceptable for both RSDs. In order to verify the method's accuracy, recovery of seven defined concentrations to experimental values that were calculated using the mean curve equation was evaluated. With reference to the ICH guidelines, the limit of detection (LOD) and limit of quantification (LOQ) were calculated using equations involving the 
standard deviation of the response of the curve and the slope of the calibration curve. Because atropine sulfate is chemically stable when stored exposed to light, light susceptibility was not examined [6].

\section{Visual inspection}

Visual inspection of the prepared atropine sulfate solutions was conducted under diffused daylight by transferring the solutions into polycarbonate test tubes. Transparency, color, and presence or absence of visible particles or haziness were verified.

\section{Osmolality and $\mathrm{pH}$ measurements}

The $\mathrm{pH}$ was measured for each sample using a $\mathrm{pH}$ meter (LAQUA D-72 T; Horiba, Kyoto, Japan) equipped with a $\mathrm{ToupH}^{\circ} \mathrm{pH}$ electrode which was calibrated at $25^{\circ} \mathrm{C}$ in $\mathrm{pH} 4$ and $\mathrm{pH} 7$ buffer solutions ( $\mathrm{pH}$ standard solution; Horiba, Kyoto, Japan). Osmolality was measured for each solution using a micro-osmometer (Auto 819 Osmomaster; Biomedical Science Co., Ltd., Tokyo, Japan).

\section{Sterility assay}

The sterility test method was validated using a method adapted from the Japanese Pharmacopoeia sterility assay (4.06), which is harmonized with the European Pharmacopoeia and the U. S. Pharmacopeia [7]. Multidose eyedroppers were opened aseptically under a laminar air flow cabinet, and the solutions filtered under vacuum using a Thermo Scientific ${ }^{\text {Tे }}$ Nalgene $e^{\circ}$ analytical test filter funnel onto a $0.45 \mu \mathrm{m}$ pore size, $47 \mathrm{~mm}$ diameter cellulose nitrate membrane (Whatman', GE Healthcare, USA). The membranes were rinsed thoroughly using $90 \mathrm{~mL}$ of Letheen broth (Difco Laboratories, New Jersey, USA), and rinsed membranes were transferred separately into either a fluid thioglycollate or soy trypticase medium, incubated at $30^{\circ} \mathrm{C}$ to $35^{\circ} \mathrm{C}$ or $20^{\circ} \mathrm{C}$ to $25^{\circ} \mathrm{C}$, respectively, for 14 days, and then examined for the presence of microbial colonies.

\section{Data analysis-acceptability criteria}

The stability of diluted atropine sulfate solutions was verified by evaluating the visual inspections and measuring atropine sulfate concentration, $\mathrm{pH}$, and osmolality.

The study was conducted in accordance with methodological guidelines [8]. Concentration ranged between 90 and $110 \%$ of initial concentration (including the limits of a $95 \%$ confidence interval of the measures), which was considered as an acceptable level of stability. The observed solutions should be colorless and transparent, with no precipitation. The $\mathrm{pH}$ measures and osmolality results were compared with the original preparation ( $1 \%$ atropine sulfate solution).

\section{Results}

Atropine sulfate quantification

Atropine retention time was $2.6 \pm 0.1 \mathrm{~min}$. The calibration curve was found to be linear for concentrations ranging between 5 and $5000 \mathrm{ng} / \mathrm{mL}$ and the determined coefficient $R^{2}$ was greater than 0.999 . The intercept was equal to zero. Recovery of $100 \mathrm{ng} / \mathrm{mL}$ was $99.0 \pm 0.01$, RSD for repeatability was $1.3 \%$, and the intermediate precision RSD was $1.5 \%$. LOD was $0.05 \mathrm{ng} / \mathrm{mL}$ and LOQ was $0.5 \mathrm{ng} / \mathrm{mL}$ (a signal-to-noise ratio of 19 for an average of six replicates).

\section{Stability of atropine sulfate in unopened multi-dose eyedroppers \\ Chemical stability}

During the experimental period, the mean concentration of six units of atropine sulfate under all conditions was more than $97.8 \%$ (Table 1 ).

\section{Physical stability}

Throughout the study, all samples stayed limpid and uncolored, for all examined concentrations and storage conditions, and visible particulate matter or turbidity was not found. Differences in osmolality from the initial value $(285 \mathrm{mOsm} / \mathrm{kg})$ were less than $1.40 \%(4 \mathrm{mOsm} / \mathrm{kg})$ at both storage temperatures (Table 2). The $\mathrm{pH}$ did not vary during the experimental period by more than 0.30 and $0.31 \mathrm{pH}$ units from initial $\mathrm{pH}(5.88)$ when stored at $5^{\circ} \mathrm{C}$ and $25^{\circ} \mathrm{C}$, respectively (Table 3 ).

\section{Sterility assay}

None of the six analyzed solutions prepared and conserved in unopened bottles at day 0 , day 14 , day 28 , or every month until six months showed any signs of turbidity and hence no evidence of microbial growth when incubated for not less than 14 days at $30-35^{\circ} \mathrm{C}$ in case of a fluid thioglycollate medium and at $20-25^{\circ} \mathrm{C}$ in the case of a soy trypticase medium.

\section{Discussion}

The diluted atropine sulfate ophthalmic solutions conserved in sterilized polyethylene eyedroppers were physicochemically stable. During six months of experimental observations, mean concentrations of atropine sulfate persisted within a 90 to $110 \%$ range of initial concentrations in polyethylene eyedropper bottles that were stored at $5{ }^{\circ} \mathrm{C}$ and $25^{\circ} \mathrm{C}$. Additionally, all the solutions that were evaluated in this study decreased no more than $3 \%$ by the end of the experiment. Visual aspects and $\mathrm{pH}$ did not change at either temperature. Osmolality also was unchanged during the six-month experimental period.

The sterility assay that was conducted following the Japanese Pharmacopoeia revealed no microbial contamination during the experimental period. Antiseptic 
Table 1 Stability of atropine sulfate concentrations for each storage condition in unopened eyedropper bottles (mean $\pm 95 \%$ confidence interval; $n=6$ )

\begin{tabular}{|c|c|c|c|c|c|c|c|}
\hline \multirow{2}{*}{$\begin{array}{l}\text { Set concentration and } \\
\text { storage temperature }\end{array}$} & \multirow{2}{*}{$\begin{array}{l}\text { Initial concentration at Day } 0 \\
(\mathrm{mg} / \mathrm{mL})(\text { mean } \pm 95 \% \mathrm{Cl})\end{array}$} & \multicolumn{6}{|c|}{ Percentage of initial Day 0 measurement (mean $\pm 95 \% \mathrm{Cl}$ ) } \\
\hline & & Day 14 & Day 28 & Day 60 & Day 90 & Day 120 & Day 180 \\
\hline \multicolumn{8}{|l|}{$0.1 \mathrm{mg} / \mathrm{mL}$} \\
\hline $5^{\circ} \mathrm{C}$ & $0.10 \pm 0.32$ & $99.00 \pm 1.35$ & $99.65 \pm 1.21$ & $98.89 \pm 2.14$ & $98.64 \pm 1.75$ & $98.45 \pm 1.00$ & $98.98 \pm 1.19$ \\
\hline $25^{\circ} \mathrm{C}$ & & $99.98 \pm 1.12$ & $98.98 \pm 0.41$ & $99.13 \pm 0.98$ & $99.31 \pm 0.98$ & $98.78 \pm 4.00$ & $99.05 \pm 3.71$ \\
\hline \multicolumn{8}{|l|}{$1.0 \mathrm{mg} / \mathrm{mL}$} \\
\hline $5^{\circ} \mathrm{C}$ & $1.00 \pm 0.41$ & $99.01 \pm 2.55$ & $99.72 \pm 2.15$ & $99.23 \pm 0.66$ & $99.18 \pm 1.95$ & $98.06 \pm 3.45$ & $99.00 \pm 1.59$ \\
\hline $25^{\circ} \mathrm{C}$ & & $100.02 \pm 1.38$ & $99.98 \pm 0.74$ & $99.65 \pm 3.03$ & $99.11 \pm 3.09$ & $98.13 \pm 4.10$ & $98.55 \pm 7.03$ \\
\hline \multicolumn{8}{|l|}{$2.5 \mathrm{mg} / \mathrm{mL}$} \\
\hline $5^{\circ} \mathrm{C}$ & $2.50 \pm 0.01$ & $99.91 \pm 1.01$ & $99.92 \pm 1.55$ & $99.84 \pm 1.20$ & $100.08 \pm 1.88$ & $98.66 \pm 6.16$ & $98.99 \pm 0.99$ \\
\hline $25^{\circ} \mathrm{C}$ & & $100.40 \pm 2.81$ & $99.94 \pm 2.54$ & $99.75 \pm 1.33$ & $99.41 \pm 4.44$ & $99.15 \pm 7.00$ & $98.55 \pm 5.33$ \\
\hline \multicolumn{8}{|l|}{$5.0 \mathrm{mg} / \mathrm{mL}$} \\
\hline $5^{\circ} \mathrm{C}$ & $5.01 \pm 0.02$ & $98.96 \pm 6.51$ & $100.10 \pm 1.66$ & $103.37 \pm 8.90$ & $101.12 \pm 3.33$ & $99.85 \pm 6.01$ & $97.87 \pm 3.68$ \\
\hline $25^{\circ} \mathrm{C}$ & & $100.05 \pm 1.33$ & $99.88 \pm 7.00$ & $99.57 \pm 0.81$ & $100.02 \pm 1.11$ & $98.07 \pm 7.06$ & $98.97 \pm 0.67$ \\
\hline
\end{tabular}

conditions during medication processing should be maintained for patient safety. Using single-dose eyedroppers is an easy way to achieve microbiological sterility; however, this practice cannot be applied to most hospital compounding departments or community pharmacies in Japan.

According to the package insert, the original 1\% atropine sulfate eye drops are described to be stable for at least 36 months before opening and 28 days after opening [9].

Our data have demonstrated that atropine sulfate maintained physicochemical stability at $25^{\circ} \mathrm{C}$ for six months without any changes in physical properties when stored in polyethylene eyedropper bottles.

The stability of atropine sulfate has described in the previous studies. Dix J et al. reported that the prepared $0.1 \%$ of atropine in $0.9 \%$ sodium chloride to treat patients exposed to acetylcholinesterase inhibitors was stable for at least 3 days at ranged $4{ }^{\circ} \mathrm{C}$ and $36{ }^{\circ} \mathrm{C}$ [10]. Donnelly RF et al. described that $0.1 \%$ of atropine in $0.9 \%$ sodium chloride were physically compatible and chemically stable when stored for 364 days at $23^{\circ} \mathrm{C}$ and exposed to light, or 364 days at $5{ }^{\circ} \mathrm{C}$ and protected from light [6]. From these facts, our findings about the chemical stability of diluted atropine solutions are in agreement with the previous studies. Regarding the sterility, the prepared atropine solutions were stored in unopened multi-dose eyedroppers. This storage condition might reduce the risk of microbial contamination. It is necessary that the sterility might not be maintained for a long duration when the product was opened [11].

Table 2 Osmolality change of atropine solutions after storage (mean \pm standard deviation; $n=6$ )

\begin{tabular}{|c|c|c|c|c|c|c|c|}
\hline \multirow{2}{*}{$\begin{array}{l}\text { Set concentration and } \\
\text { storage temperature }\end{array}$} & \multirow{2}{*}{$\begin{array}{l}\text { Initial osmolality at Day } 0 \\
(\mathrm{mOsm} / \mathrm{kg})(\text { mean } \pm \mathrm{SD})\end{array}$} & \multicolumn{6}{|c|}{ Osmolality values (mean \pm SD) } \\
\hline & & Day 14 & Day 28 & Day 60 & Day 90 & Day 120 & Day 180 \\
\hline \multicolumn{8}{|l|}{$0.1 \mathrm{mg} / \mathrm{mL}$} \\
\hline $5^{\circ} \mathrm{C}$ & $285 \pm 0.55$ & $285 \pm 3.61$ & $285 \pm 2.70$ & $285 \pm 1.11$ & $285 \pm 1.88$ & $285 \pm 0.96$ & $285 \pm 1.34$ \\
\hline $25^{\circ} \mathrm{C}$ & & $285 \pm 1.02$ & $285 \pm 2.13$ & $285 \pm 3.31$ & $285 \pm 1.41$ & $285 \pm 1.66$ & $285 \pm 1.14$ \\
\hline \multicolumn{8}{|l|}{$1.0 \mathrm{mg} / \mathrm{mL}$} \\
\hline $5^{\circ} \mathrm{C}$ & $285 \pm 0.61$ & $285 \pm 1.50$ & $285 \pm 3.61$ & $286 \pm 3.33$ & $286 \pm 2.48$ & $285 \pm 0.82$ & $286 \pm 2.74$ \\
\hline $25^{\circ} \mathrm{C}$ & & $286 \pm 0.22$ & $285 \pm 3.15$ & $286 \pm 3.78$ & $285 \pm 1.40$ & $285 \pm 2.35$ & $286 \pm 2.84$ \\
\hline \multicolumn{8}{|l|}{$2.5 \mathrm{mg} / \mathrm{mL}$} \\
\hline $5^{\circ} \mathrm{C}$ & $285 \pm 0.54$ & $285 \pm 0.81$ & $285 \pm 2.11$ & $286 \pm 3.21$ & $286 \pm 2.66$ & $285 \pm 0.32$ & $286 \pm 3.54$ \\
\hline $25^{\circ} \mathrm{C}$ & & $284 \pm 1.12$ & $286 \pm 1.04$ & $286 \pm 1.78$ & $286 \pm 1.41$ & $286 \pm 1.41$ & $286 \pm 1.00$ \\
\hline \multicolumn{8}{|l|}{$5.0 \mathrm{mg} / \mathrm{mL}$} \\
\hline $5^{\circ} \mathrm{C}$ & $285 \pm 0.54$ & $286 \pm 1.03$ & $285 \pm 2.09$ & $285 \pm 0.99$ & $285 \pm 0.86$ & $286 \pm 1.74$ & $287 \pm 0.51$ \\
\hline $25^{\circ} \mathrm{C}$ & & $286 \pm 1.08$ & $283 \pm 1.97$ & $286 \pm 0.87$ & $286 \pm 1.41$ & $287 \pm 4.11$ & $286 \pm 0.54$ \\
\hline
\end{tabular}


Table $3 \mathrm{pH}$ change of atropine solutions after storage (mean \pm standard deviation; $n=6$ )

\begin{tabular}{|c|c|c|c|c|c|c|c|}
\hline \multirow{2}{*}{$\begin{array}{l}\text { Set } \\
\text { concentration } \\
\text { and storage } \\
\text { temperature }\end{array}$} & \multirow{2}{*}{$\begin{array}{l}\text { Initial pH } \\
\text { at Day } 0 \\
\text { (mean } \pm \\
\text { SD) }\end{array}$} & \multicolumn{6}{|c|}{$\mathrm{pH}$ values (mean $\pm \mathrm{SD})$} \\
\hline & & Day 14 & Day 28 & Day 60 & Day 90 & Day 120 & Day 180 \\
\hline \multicolumn{8}{|l|}{$0.1 \mathrm{mg} / \mathrm{mL}$} \\
\hline $5^{\circ} \mathrm{C}$ & $5.90 \pm 0.40$ & $5.91 \pm 1.09$ & $5.84 \pm 0.15$ & $5.77 \pm 1.63$ & $5.69 \pm 1.18$ & $5.61 \pm 1.16$ & $5.61 \pm 1.09$ \\
\hline $25^{\circ} \mathrm{C}$ & & $5.92 \pm 1.06$ & $5.80 \pm 1.95$ & $5.70 \pm 1.84$ & $5.66 \pm 1.27$ & $5.59 \pm 1.51$ & $5.61 \pm 1.99$ \\
\hline \multicolumn{8}{|l|}{$1.0 \mathrm{mg} / \mathrm{mL}$} \\
\hline $5^{\circ} \mathrm{C}$ & $5.88 \pm 0.30$ & $5.88 \pm 0.99$ & $5.74 \pm 0.85$ & $5.74 \pm 1.33$ & $5.65 \pm 0.14$ & $5.60 \pm 0.86$ & $5.58 \pm 0.99$ \\
\hline $25^{\circ} \mathrm{C}$ & & $5.88 \pm 1.05$ & $5.70 \pm 0.95$ & $5.73 \pm 0.74$ & $5.65 \pm 0.77$ & $5.60 \pm 0.08$ & $5.57 \pm 0.70$ \\
\hline \multicolumn{8}{|l|}{$2.5 \mathrm{mg} / \mathrm{mL}$} \\
\hline $5^{\circ} \mathrm{C}$ & $5.88 \pm 0.31$ & $5.88 \pm 0.31$ & $5.74 \pm 1.37$ & $5.74 \pm 0.79$ & $5.65 \pm 0.12$ & $5.60 \pm 0.41$ & $5.58 \pm 0.39$ \\
\hline $25^{\circ} \mathrm{C}$ & & $5.88 \pm 0.05$ & $5.70 \pm 0.61$ & $5.70 \pm 0.94$ & $5.65 \pm 0.74$ & $5.60 \pm 0.12$ & $5.57 \pm 0.32$ \\
\hline \multicolumn{8}{|l|}{$5.0 \mathrm{mg} / \mathrm{mL}$} \\
\hline $5^{\circ} \mathrm{C}$ & $5.88 \pm 0.41$ & $5.88 \pm 0.11$ & $5.74 \pm 0.39$ & $5.71 \pm 0.93$ & $5.70 \pm 0.44$ & $5.68 \pm 0.15$ & $5.68 \pm 0.11$ \\
\hline $25^{\circ} \mathrm{C}$ & & $5.88 \pm 0.47$ & $5.69 \pm 0.55$ & $5.68 \pm 0.19$ & $5.67 \pm 0.32$ & $5.68 \pm 0.45$ & $5.68 \pm 0.66$ \\
\hline
\end{tabular}

As with the diluted atropine eye drops, several active pharmaceutical ingredients were prepared as eye drops from the commercially available injections [12-14], eye drops [15] or chemical agents [16]. Most of all cases were antibiotic or antifungal agents, and the stability and sterility were investigated [12-14]. The biological activities, clinical efficacy, safety and pharmacokinetics of these drugs also indicated in some prepared eye drops [15-20]. Despite the increased needs of eye drops in various fields of medicine, many products are still extemporaneously prepared in hospital, and assurance of safety and efficacy of prepared products are needed in each hospital for use. Considering these facts, appropriate medicinal products that answer the needs of clinical settings might be needed.

In this study, atropine sulfate eye drops at $0.1,1.0,2.5$, and $5.0 \mathrm{mg} / \mathrm{mL}$ diluted using $0.9 \% \mathrm{NaCl}$ that were stored in polyethylene eyedropper bottles were physiologically stable and no obvious physical property change was found during six months of experimental observations.

\section{Conclusions}

This study validated the physical, chemical, and microbiological stability of $0.1,1.0,2.5$, and $5.0 \mathrm{mg} / \mathrm{mL}$ atropine sulfate eye drops conserved inside polyethylene eyedroppers for six months at $25^{\circ} \mathrm{C}$ or $5{ }^{\circ} \mathrm{C}$. These information may serve as useful data for preparation of diluted atropine eye drops for pediatric patients.

\section{Abbreviations \\ LC: liquid chromatography; LOD: limit of detection; LOQ: limit of quantification; RSD: relative standard deviation}

\section{Acknowledgements}

We really appreciate Hideki Nakajima providing us with the LC-MS/MS equipment for the quantitative analysis. We also thank Dr. Clifford A. Kolba
(National Center for Child Health and Development, Department of Education for Clinical Research, Japan) for his dedicated English editorial support.

\section{Authors' contributions}

$J S$ and $\mathrm{HI}$ performed the research. JS, $\mathrm{HI}$, and AY designed the research study. JS and $\mathrm{HI}$ analyzed the data. JS, HI, and AY wrote the manuscript. All authors read and approved the final manuscript.

\section{Funding}

None.

Availability of data and materials

None.

\section{Ethics approval and consent to participate}

N/A

\section{Consent for publication}

N/A

\section{Competing interests}

The authors declare that they have no competing interests.

Received: 24 September 2019 Accepted: 12 November 2019 Published online: 05 December 2019

\section{References}

1. Kothari M, Rathod V. Efficacy of $1 \%$ atropine eye drops in retarding progressive axial myopia in Indian eyes. Indian J Ophthalmol. 2017;65:117881.

2. Shih YF, Chen $\mathrm{CH}$, Chou AC, Ho TC, Lin LL, Hung PT. Effects of different concentrations of atropine on controlling myopia in myopic children. J Ocul Pharmacol Ther. 1999;15:85-90.

3. Chia A, Chua WH, Cheung YB, Wong WL, Lingham A, Fong A, Tan D. Atropine for the treatment of childhood myopia: safety and efficacy of 0.5 , 0.1 , and $0.01 \%$ doses (atropine for the treatment of myopia 2). Ophthalmology. 2012;119:347-54.

4. Wakayama A, Nishina S, Miki A, Utsumi T, Sugasawa J, Hayashi T, Sato M, Kimura A, Fujikado T. Incidence of side effects of topical atropine sulfate and cyclopentolate hydrochloride for cycloplegia in Japanese children: a multicenter study. Jpn J Ophthalmol. 2018;62:531-6.

5. Koželj G, Perharič L, Stanovnik L, Prosen H. Simple validated LC-MS/MS method for the determination of atropine and scopolamine in plasma for clinical and forensic toxicological purposes. J Pharm Biomed Anal. 2014;96: 197-206. 
6. Donnelly RF, Corman C. Physical compatibility and chemical stability of a concentrated solution of atropine sulfate $(2 \mathrm{mg} / \mathrm{mL})$ for use as an antidote in nerve agent casualties. Int J Pharm Compd. 2008;12:550-2.

7. The Ministry of Health, Labour and Welfare, The Japanese Pharmacopoeia 17th Edition, 2016. Monographs No. 4.06. https://www.mhlw.go.jp/stf/ seisakunitsuite/bunya/0000066597.html Accessed 11.14.2019.

8. Guidance for industry Q1A (R2) Stability testing of new drug substances and products. U.S. Department of Health and Human Services, Food and Drug Administration, Center for Drug Evaluation and Research and Center for Biologic Evaluation and Research, 2003. http://www.fda.gov/downloads/ drugs/guidancecomplianceregulatoryinformation/guidances/ucm073369.pdf Accessed 11.14.2019.

9. Package insert, Nitten Atropine Ophthalmic Solution 1\%, Nitten Pharmaceutical Co., Ltd., 2010.

10. Dix J, Weber RJ, Frye RF, Nolin TD, Mrvos R, Krenzelok E. Stability of atropine sulfate prepared for mass chemical terrorism. J Toxicol Clin Toxicol. 2003;41: $771-5$.

11. Oldham GB, Andrews V. Control of microbial contamination in unpreserved eyedrops. Br J Ophthalmol. 1996;80:588-91.

12. Curti C, Lamy E, Primas N, Fersing C, Jean C, Bertault-Peres P, Vanelle P. Stability studies of five anti-infectious eye drops under exhaustive storage conditions. Pharmazie. 2017:72:741-6.

13. Okumura N, Tanaka T, Fukui Y, Koizumi N. Stability, safety, and pharmacokinetics of ganciclovir eye drops prepared from ganciclovir for intravenous infusion. Jpn J Ophthalmol. 2019;63:289-96.

14. Ratprasatporn N, Wittayalertpanya S, Khemsri W, Chatsuwan T, Chongpison Y, Chamsai T, Wattanakijkarn M, Chansangpetch S. Stability and sterility of extemporaneously prepared nonpreserved Cefazolin, Ceftazidime, Vancomycin, amphotericin B, and methylprednisolone eye drops. Cornea. 2019;38:1017-22

15. Kim DH, Stark WJ, O'Brien TP, Dick JD. Aqueous penetration and biological activity of moxifloxacin $0.5 \%$ ophthalmic solution and gatifloxacin $0.3 \%$ solution in cataract surgery patients. Ophthalmology. 2005;112:1992-6.

16. Koch HR, Kulus SC, Roessler M, Ropo A, Geldsetzer K. Corneal penetration of fluoroquinolones: aqueous humor concentrations after topical application of levofloxacin $0.5 \%$ and ofloxacin $0.3 \%$ eyedrops. J Cataract Refract Surg. 2005:31:1377-85

17. Dreno C, Gicquel T, Harry M, Tribut O, Aubin F, Brandhonneur N, Dollo G. Formulation and stability study of a pediatric $2 \%$ phenylephrine hydrochloride eye drop solution. Ann Pharm Fr. 2015;73:31-6.

18. Neoh CF, Leung L, Chan E, Al-Badriyeh D, Fullinfaw RO, Jhanji V, Vajpayee RB, Davies GE, Stewart K, Kong DC. Open-label study of absorption and clearance of $1 \%$ Voriconazole eye drops. Antimicrob Agents Chemother. 2016:60:6896-8.

19. Camp NA, Nadra JT, Hughes SE, Gilbert JM, Zhao F. Stability of extemporaneously prepared ophthalmic solutions for mydriasis. Am 」 Health Syst Pharm. 2018;75:e231-5.

20. Gyanfosu L, Koffuor GA, Kyei S, Ababio-Danso B, Peprah-Donkor K, Nyansah WB, Asare F. Efficacy and safety of extemporaneously prepared miconazole eye drops in Candida albicans-induced keratomycosis. Int Ophthalmol. 2018; 38:2089-100.

\section{Publisher's Note}

Springer Nature remains neutral with regard to jurisdictional claims in published maps and institutional affiliations.

Ready to submit your research? Choose BMC and benefit from:

- fast, convenient online submission

- thorough peer review by experienced researchers in your field

- rapid publication on acceptance

- support for research data, including large and complex data types

- gold Open Access which fosters wider collaboration and increased citations

- maximum visibility for your research: over $100 \mathrm{M}$ website views per year

At BMC, research is always in progress.

Learn more biomedcentral.com/submissions 